\title{
Portrait of politeness in language by the supporters of governor's candidates in the discourse of Jakarta election
}

\author{
Agustina* and Syahrul R \\ Indonesian Language and Literature Department \& Regional Language, Faculty of Language and Arts, Padang State \\ University, Indonesia. \\ *Corresponding author. E-mail: tien_agustina08@yahoo.com
}

Accepted 20 September, 2017

\begin{abstract}
Jakarta Election 2017 can be categorized as phenomenal and controversial. This is not only because of the political process in it, but also in the use of language as its political means. Based on the data found in mass media, a language in relation to the seizure of power has become a political tool so that it is worthless because it turns function into means of cursing, abusing and exposing the ill-favored. Furthermore, the language even serves as a tool for waging conflict, hatred, SARA sentiment, and character assassination. Such phenomena are not only exhibited by the political elite of each candidate, but also by the supporting community of governor's candidates in social media through their Instagram community account. Based on above reasons, this study becomes important because language in political discourse is no longer bringing the clarity of meaning and resulting in language manipulation and deviation of language function as tool of cooperation. Moreover, this article is part of the result of the research entitled: Verbal violence in Political Discourse during Jakarta Election: A study of SocioPragmatic Discourses.
\end{abstract}

Key words: Politeness, speech acts, Jakarta election, supporters of governor.

\section{INTRODUCTION}

Functionally, language is a tool for communicating for the user community. This is inseparable from the social function of man who must interact with others and communicate his opinions and views in an understandable language. Pragmatic, as a part of linguistics, in carrying out its role as a communication tool and as a tool of interaction between human beings, requires three components needed in the process of communicating, i.e. communicating parties (speaker and hearer), information provided (contents and messages) and tools used (speech and way of disclosure). Therefore, a communication in a pragmatic perspective can be categorized successfully if it is marked by the presence of reaction from the listener that the content or message conveyed is communicative; not a reaction in the form of a complaint that leads to prolonged protests, protests, or polemics (Agustina, 2017). Furthermore, in terms of the potential and effect of contextual meaning, language is very effective for creating influence as a political tool. Therefore, in political events, especially on electoral events related to power struggles (president or regional head), this often affects the use of language, especially in the use of diction, term and phrase.

This phenomenon also appeared in recent Jakarta election. Based on the results of the research, it was revealed that some of the news packaged in certain forms and styles of disclosure used by political elites, journalists, and community supporters of the governor's candidate, tends to be abusive, berate, spread the hardto-answer issues, even tends to distort the facts that can potentially cause unrest in society, prolonged conflict, hatred, SARA sentiments, and assassination of political opponents character (Agustina, 2017).

Based on the above statement, this research has an important place related to the stability and security of the country. Apparently, the use of language in political discourse in the mass media is no longer bringing the clarity of meaning because it has been manipulated for 
the interests of political elites and certain groups, resulting in language manipulation and deviation of language functions as a tool of cooperation. This discussion attempts to capture and to map the politeness of language from the community supporters of governor candidates which is voicing the discourse of Jakarta election in social media through their instagram account.

\section{Problems and Objectives}

This discussion is based on one of the problems proposed in the study, namely: "How is the portrait of language politeness from the supporters of candidates in the political discourse of the Jakarta Election?". To answer the problem, the discussion section will contain four specific objectives such as to define and describe: (1) what the types of speech acts are used, (2) the selected expression forms, (3) the speech act strategies applied, and (4) how is the application of the principles of politeness by supporters of candidates in the political discourse of Jakarta election? Thus, the aim of this research is to determine the position/scale of politeness used by the society supporters of candidates in political discourse of Jakarta election.

\section{Theoretical frameworks}

\section{Pragmatics}

One branch of linguistics that discusses how the language is used in contextual communication is called pragmatics. Pragmatics is used as the main theory in this discussion along with the concept of politeness and speech acts. Pragmatics is a study of languages that study the relations of language with its context (Levinson, 1983); discussion of meaning to speech situations (Leech, 1993); a study of the ability of language-user to link and to harmonize sentences with its context (Agustina, 217); and the study of how the language is used in communication (Wijana, 1996). It can be concluded that pragmatics examines the rules of the use of language form and meaning related to the intentions of the speaker under the context and function of the speech. Thus, in the discussion of speech discourse in Jakarta election, the context of political development around Jakarta election becomes very crucial in tracking the function and meaning of the written expression.

\section{Politeness}

In the pragmatic study, politeness is a procedure or habit in the form of social behavior that is determined and agreed upon by a particular society. Thus, politeness is a system of interpersonal relations designed to help interaction by minimizing the potential for conflict and confrontation (Lakoff in Syahrul, 2008); property associated with the speech where the speaker does not transcend the right of the hearer in fulfilling his/her obligations in a speech event (Frasser, in Chaer and Leoni, 2010). So, politeness is a universal phenomenon because in communicating, the norms apply to the use of any language in the world. But, in reality politeness is a complex phenomenon. Politeness is changing due to the influence of dynamic interaction between language, culture, and social values (Yaolong, 2008).

Thus, Leech (1993) explains that politeness is an attempt to create mutual trust and the presence of rude opinions to be as small as possible by obeying the six principles of politeness as follows: (a) Tact maxim: minimizes the expression of beliefs which imply cost to other; maximizes the expression of beliefs which imply benefit to other; (b) Generosity maxim: minimizes the expression of beliefs that express or imply benefit to self; maximizes the expression of beliefs that express or imply cost to self; (c) Praise maxim: minimizes the expression of beliefs which express dispraise of other; maximizes the expression of beliefs which express approval of other; (d) Modesty maxim: minimizes the expression of praise of self; maximizes the expression of dispraise of self; (e) Agreement maxim: minimizes the expression of disagreement between self and other; maximizes the expression of agreement between self and other; ( $f$ ) Sympathy maxim: minimizes antipathy between self and other; maximizes sympathy between the self and other.

Functionally, politeness in relation to avoidance of a conflict, with the concept of face referring to "self-image", is something that is emotionally invested (which can be treated, lost or abandoned) and which must be consistently present in the interaction (Brown and Levison, 1987); which manifests into a negative face and positive face (Yule, 2006). According to Brown and Levinson (1987), the concept of the face is universal and tends to relate to unpleasant actions or threatening a face.

In communicating, the role of the speaker is not only to convey information but also to maintain and preserve the social relations between speakers and listeners (Gunarwan, 1994). For this reason, Grice redefined that assumption as "to select an utterance that does not underestimate the status of the listener or the utterance causes the lowest risk of losing face", with details: (1) do not treat the listener as a party that is subject to the speaker, or the party affected by the social cost, physical cost, psychological cost, or limits their freedom; (2) do not say unfavorable things about other people or stuffs related to the listener; and (3) do not express the pleasure over the misfortune of listener (in Pranowo, 2009).

In line with that, to determine the level of politeness, we can use politeness scales proposed by Brown and Levinson (1987) based on Face Threatening Acts (FTA) 
with two parameters: (1) Negative threatening actions, such as command, threat, warning, challenge, hatred, anger, etc. (2) Positive threatening action, in the form of criticism, humiliation, accusation, humiliation, etc. along with provocative utterance which can divide races, religions, and unsuitable representation. Besides, the researchers also used the 'scale of indirectness' of BlumKulka (1985) with the formula "The more direct you deliver the speech, the less polite your utterance; but the more indirect you deliver the speech, the more polite your utterance."

\section{Speech Acts}

Speech Act is a statement that contains action under the speech (Sherry et al., 2012). The scale of politeness in a conversation can be traced to the type of speech acts used, the chosen form of expression, and the speech strategy.

Based on the theory of Searle (1975), there are five types of speech acts that determine politeness: (1) Assertive speech acts: including the speakers to the truth of what he says, such as: stating, reporting, demonstrating, and mentioning. This type has a higher level of vulnerability related to the truth of a statement, the politeness tend to be neutral because it belongs to the category of cooperation, unless it is being boasted; (2) Directive speech act: directing the listener to do what the speaker says, in the form of ordering, pleading, suggesting, asking, patronizing, and advising; which serves a pleasant function, except to instruct and to patronize that potentially to threathen the face so that it can be softened with imperative of allowing, inviting, and banning (Rahardi, 2000); (3) Expressive speech acts: this type aims to evaluate a situation, such as: praising, criticizing, thanking, and complaining, but criticizing and the like are competitive and tend to threaten the face of listener; (4) Commissive speech acts: aims to bind its speakers to carry out what is mentioned, such as pledging, swearing, forcing, condemning, and threatening; has an unpleasant function and very potential to threaten the face of listener; (5) Declaration speech acts: aims to creating new status or circumstances, such as: deciding, withdrawing, allowing, prohibiting, influencing, and forgiving; it is practiced by authorized speakers.

The use of the types of speech acts above move along with its function in speaking. Leech (1993) classifies the function of illocution on the basis of its relation to social objectives of maintaining polite and respectful manners, in four functions: (1) The competitive function: the illocutionary goal competes with the social goal. This negative politeness aims to reduce the implied disharmony in competition, between what is to be achieved and what is demanded in politeness; (2) Convivial function: the illocutionary goal coincides with the social goal, which is more positive-shaped politeness and aims to find opportunities to be polite; (3) Collaborative function: the illocutionary goal is indifferent to the social goal; (4) Conflictive function: the illocutionary goal conflicts with the social goal, where there is no politeness at all because it aims to generate anger, such as threatening, accusing, cursing, and offending.

The application of politeness strategy aims to reduce the disappointment of the listener over the actions performed by the speaker. In this study, the politeness strategy refers to the notion of Brown and Levinson (1987), which is (1) bald on-record, (2) positive politeness, (3) negative politeness, (4) be vague, and (5) off-record. Bald on-record strategy according to BlumKulka (1985) is a direct speech so this strategy has full potential to threaten the face of the addressee.

The application of this strategy according to Brown and Levinson (1987) should be based on a decision: (1) If the speaker wants to keep the face of the hearer, then try to speak politely; (2) If the speaker wants to violate the positive face of the listener (for his acceptance and acknowledged good image), then the speaker uses a positive politeness strategy; (3) If the speaker wants to violate the negative face of the listener (violates the desire of the speaker not to be disturbed or undermined his/her rights), then the speaker uses a negative politeness strategy.

However, the politeness of a speaker is also determined from the form of expression, such as diction or figure of speech which he/she chooses as a medium. To investigate this case, here are some classification of language styles and types of figure of speech that follows: (a) assertive style, with figure of speech like pleonasm, hyperbole, litotes, repetition, climax, anticlimax, asyndeton, polysindeton, epanorthosis, and interruption; (b) comparative style, with figure of speech like metaphorical, personification, tropen, metonymy, and synecdoche (pars prototo and totem proparte); (c) contradictive styles, with figure of speech like paradoxical and antithesis; and (d) satire style, with figure of speech like sarcasm, cynicism, irony, allusion, and paradox (Keraf, 2007).

\section{METHODOLOGY}

The methodology applied in this discussion is the qualitative research as the event of Jakarta election is the natural object (Moleong, 2010); is also the descriptive nature that prioritizes the depth of appreciation to interaction of the among concepts which are being studied empirically (Semi, 1993).

The data of this research are sentences containing political expression in the political discourse of the Jakarta election, especially in the form of opinion/comments in social media through instagram account of the supporter community of the candidates, among others: @gembonk.politik (GP), @potretpolitik 
Table 1. Classification of elements usage and political scale supporters of candidates in the discourse of Jakarta election.

\begin{tabular}{|c|c|c|c|c|c|c|c|c|c|c|c|}
\hline \multicolumn{9}{|c|}{ Element of Politeness } & \multicolumn{3}{|c|}{ Scale of Politeness } \\
\hline $\begin{array}{l}\text { Type of } \\
\text { Illocution }\end{array}$ & Total & $\begin{array}{l}\text { Diction and } \\
\text { Figure of Speech }\end{array}$ & Total & Politeness Strategy & Total & $\begin{array}{l}\text { Politeness } \\
\text { Principle }\end{array}$ & Obey & Violate & $\%$ & $\begin{array}{l}\text { Face } \\
\text { Level }\end{array}$ & Classification \\
\hline Expressive & 46 & Sarcasm & 43 & Bald on-record & 59 & Wisdom & 1 & 38 & 62 & \multirow{2}{*}{ High } & \multirow{2}{*}{ Impolite } \\
\hline Commissive & 43 & Cynicism & 35 & Negative politeness & 31 & Generous & 0 & 8 & & & \\
\hline Directive & 13 & Irony & 7 & Positive politeness & 2 & Compliement & 1 & 3 & 36 & \multirow{3}{*}{$\begin{array}{l}\text { Quite } \\
\text { High }\end{array}$} & \multirow{3}{*}{ Less Polite } \\
\hline Declarative & 0 & Alusio & 15 & Vague & 10 & Modesty & 0 & 7 & & & \\
\hline Assertive & 0 & Paradox & 2 & - & & Agreement & 0 & 12 & 12 & & \\
\hline- & & - & & - & & Sympathy & 0 & 23 & & \multirow{3}{*}{$\begin{array}{l}\text { Not high } \\
\text { enough }\end{array}$} & \multirow{3}{*}{ Quite Polite } \\
\hline- & & - & & - & & Considerence & & 9 & 100 & & \\
\hline Total & 102 & Total & 102 & Total & 102 & Total 102 & 2 & 100 & & & \\
\hline
\end{tabular}

(PP), @politikcrazy.id (PC), @politikkampus (PK), @trolali.id (TL), @warkop.id (WI), and @dpp.fpi (DF) which was downloaded randomly in a period of January-April 2017, during the campaign until the winner's determination. The selection of this research object, in terms of both content and data sources, is based on the following considerations: (1) the focus of research, which is the type, form of expression, the spoken strategy used, and the principle of politeness that is obeyed or violated; (2) the target of research, namely the elections of DKI as one of the barometer of political situation in Indonesia; (3) the type and value of literacy/discourse chosen, that is influencing the public interest because social media has been classified into public speaking; (4) the level of user community/consumer discourse, i.e. representing aspects of education, age, and social status of the general public.

Analyzing data through content analysis method was done to reveal, understand, and capture messages in data, and make conclusions obtained through identification and interpretation of data (Endraswara, 2011).

\section{RESULTS}

Based on the identification of data in accordance with the problems proposed in this study, the researcher obtained the recapitulation of data classification result for the use of the politeness element, and the politeness level of the supporters of governor's candidates in the political discourse of the Jakarta election can be presented in Table 1

\section{The use of speech acts by the supporters of governor's candidates in the political discourse of the Jakarta election}

Based on the data classification, there are four types of speech acts used by the community of supporters in expressing their opinions. The most dominant act of speech used is expressive which aims to evaluate what is said, it is expressed in five ways: criticizing (1), mocking (2), insulting (3), and complaining (4).

1. Jakarta butuh aksi! Bukan teori basi atau retorika fantasi (PP- 8).

'Jakarta needs an action! Not an outdated theory or imaginary rhetoric

2. ANIES di bibir, pintar berSANDIwara (PP13)

'ANIES on his lips, just make a song'.

3. Ahok murka disebut kafir di persidangan. Terus, maunya disebut ustadz gitu? Yeeechhh kaleng khong guan! (DF-8).

'Ahok was angry while called as kafir in the court. So he want to be called as ustadz? Ugh, nonsense like kong guan can!'.

4. Hanya karena minoritas, semua pengorbanan dan kebaikan kalah dalam hukum karena keadilan diintervensi oleh ormas radika!! (PC-1).

'All of his sacrifices and goodness were gone with his minority status and interventioned law by the radical group!'.

The choice of expressive speech acts by criticizing, mocking, humiliating, and complaining indicates that the community is not trying to speak politely. This behavior creates a 'very high' level of face vulnerability because the goal of this speech is competitive. In most of their speeches, the purpose of the illocution is to compete with 
the social objective so that politeness are negative and its purpose is to reduce disharmony.

The next dominant speech acts used are commissive, which binds the speakers to realize and to manifest their statements. It is stated in three ways, viz., condemning (5), threatening (6), and forcing (7).

5. Pengkhianat-pengkhianat NKRI bermain di belakang nama agama, suruh pengkhianat itu belajar sejarah Indonesia lagi, Indonesia bukan Negara agama (PK-3).

'The traitors of Indonesia wear a mask of religion, tell them to study the History of Indonesia again, it is not a religious-based country'.

6. Silakan Anda jadikan Ahok sebagai nabi kalian, tapi jangan sekali-kali nodai Islam dan perjuangan umat Islam. Atau kamu akan kami habisi dengan cara kami? (DF-3).

'You may refer Ahok as your prophet, but never blemish Islam and its struggle. You want to die in our way, don't you?'.

7. Pak Presiden, jika kau takut bila penista Al-Quran dipenjara rahasiamu akan terbongkar, maka hukum mati saja penista agama itu (DF-2).

'Mr. President, if you afraid as Blasphemer of Quran reveal your secret at prison, so please sentence the blasphemer of Quran to the death'.

Although commissive speech acts are generally less competitive, but the use of a very negative diction such mocking, threatening, forcing binds the speaker to commit his intention, so the level of face vulnerability is 'very high.' In the above speech, the function of illocution is contradictory (conflictive) with social goals, which is no politeness at all because it is intended to cause a disharmony.

Another type of speech acts used by the supporters is directive, a speech that asks the addressee to do something, which is delivered in the form; demanding (8), challenging (9), warning (10), advocating (11), and appealing (12).

8. Mohon doa restunya. Penjarakan Ahok SECEPATNYA (WI-13).

'Hope for blessing, Ahok in jail as soon as possible.

9. Jika ngaji dan bela kehormatan Ulama dan Islam dicap Radikal, tolong masukkan nama gue dalam kaum radikal tersebut (WI-10).

'If studying Islam and respecting the Ulama is noted as a radical, so please insert my name in that radical list'.

10. Agamaku adalah kekuatanku maka janganlah engkau salahkan kitabku (TL-5)

'My religion is my power, so do not ever blame my holly book'.

11. Kalo dipersulit pas mau nyoblos, bilang aja mau nyobolos Anies-Sandi. Tapi pas di bilik suara, coblos nomor 2 (GP-5).

'If you can not vote as normal, just simply say you will vote Anies-Sandi. However, in the voting-room, you can vote for number two'.

12. Pilih pemimpin yang merajut tenun kebangsaan, bukan yang merobeknya demi kekuasaan (PP-11).
'Choose a leader that builds a national stability, not a destroyer one for the sake of a throne'.

From the above utterances, the form of demanding and chalengging have the highest level of vulnerability and the form of noticing, advising and urging have less possibility to threaten the face of addressee. In this case, the illocutionary goal is indifferent to the social goal because politeness is no longer relevant.

The use of diction and figure of speech by the supporters of governor's candidate in the discourse of Jakarta election

People who are members of this supporting community, in their opinion and comment, generally use dictions and utterance that tend to lead to a verbal violence. Although they interact in social media, they are indirectly already in the public speaking sphere. The facts can be seen in the following data that the supporting community only uses satirical language styles through: sarcasm (13), cynicism (14), irony (15), alusio (16), and paradox (17).

13. Ahok = kafir, Djarot=Muslim, Ingat!! Samyang jadi haram bukan karena mienya, tapi ada minyak babinya! (TL-7).

'Ahok= Kafir, Djarot=Moeslem, Remember!! Samyang is forbidden not because of its noodle, but that of pork oil'.

14. Hasil jual agama dapet DKI 1.Di Jakarta apapun bisa dijual (PK-1).

'Business of religion can get you a DKI-1. Everything can be sold".

15. Maling ayam 3 tahun penjara, Penista Agama??? (WI16).

'Chicken theft is 3 years in prison. Blasphemy??'.

16. Jual ayat demi syahwat, teriak beriman tapi kelakuan siluman (PK-4).

'Sell holly verse for lust, shouted for faith but satanic behaviour'.

17. Hukum tajam ke minoritas, tumpul ke mayoritas (PC2)

'One law for the majority, no law for the minority'.

The delivery of comments by these supporting communities through their instagram accounts are generally done through direct, open, and massive sarcasm and cynicism followed by rough, bitter, and foul words. It occupies a 'very high' possibility to threaten the face of the recipients.

This supporting community also uses other figure of speeches like Irony, Alusio, and Paradoxical even though it is not too significant. However, the selected diction includes the category of verbal violence, thereby it is likely to 'threatening a positive face.' Based on the data presented above, it can be concluded that the supporting community of governor's candidates of Jakarta disregarded Grice formulation by Pronowo (2000): "to choose an utterance that does not underestimate the status of recipient or to create an expression that has the 
smallest possibility to lead to a face-losing."

\section{The application of speech strategy in the discourse of Jakarta election}

The four types of strategies chosen by the supporting community in expressing their opinions about the Jakarta election are the: bald on-record strategy (18), negative politeness (19), positive politeness (20), and be vague strategy (21).

18. Mau pilih paslon 3? Dijamin tidak menyelesaikan masalah, justru menambah masalah baru (PK-9)

'You vote for number 3? I guarantee it will not solve the problem; however, just make the new one'.

19. Saya Muslim, saya sedih Ahok dipenjara, tapi saya bangga Ahok dihukum mati (WI-1).

'I am a Muslim and i am sad with Ahok in jail, but i am proud if Ahok is sentenced to death'.

20. Ketika kalian menangis junjungan kalian di penjara, kami juga menangis ketika Kitab Suci kami dihina (WI-7).

'When you cry for your idol in prison, we also cried when our holly book was insulted'.

21.Sidang Ahok ditunda? Ya iyalah, kan kejaksaan agung orang nasdem? (WI-21).

'Ahok trial is postponsed? No wonder, the officials are their group, right?'

More than half of the total data (59 data) is expressed by the supporting community with bald on-record strategy. This surprising fact is due to high interest and expectations of the supporters of both candidates so they do everything possible to justify their choice. Ultimately, both supporters are no longer considering the laws of politeness in the language.

From 'scale of indirectness', this bald on-record strategy belongs to 'direct speech', whereas based on the 'scale of vulnerability', this strategy is very high to threaten the face of recipient. Although three other strategies such as negative politeness, positive politeness, and be vague, includes into 'indirect speech', they are still categorized as threatening face due to negative word choices.

Implementation of the principle of politeness by community supporters of governor's candidates in Jakarta election

To create a polite speech, the experts offer seven principles of politeness that speakers should choose according to the needs and context of speech. In this study, out of a total of 102 utterances, there are only 2 expressions that adhere to the principle of politeness, while the other 100 data clearly violate the principle of politeness. The most violated principles among others; tact (22), sympathy (23), and agreement (24). Another violated principles but minimum are consideration (25), generosity (26), modesty (27), and approbation (28).

22. Tembak mati pelaku makar! Presiden sedang gencar2nya membangun bangsa guna mewujudkan keadilan sosial, eh lah kok ada yang coba-coba mau makar? Kalian ini bangsat atau keparat? Dasar manusia jahanam (PK-11).

'Shoot dead the betrayal! President in rush for manifesting the social justice and you tried to betray the state? You are a rogue or moron? The scum of the earth'.

23. Kemesraan Anies, Khilafah, Radikalisme, dan Terorisme (GP-6).

'The intimacy between Anies, caliphate, radicalism and terrorism'.

24. Muslim yang pilih ahok bukan tak percaya Almaidah 51, tapi karena tidak percaya Anies (GP-3)

'Muslim who vote for Ahok are faithful for Al maidah 51, but disbelief of Anies'.

25. Selama ini kita tahu hanya program jualan SARA dan nyerang pribadi lawan yang banyak dilakukan. Ini bukti betapa 'murahannya' program yang diusung Anies, dan ini juga sebagai bukti Anies tak layak jadi Gubernur DKI (PK-13).

'We only know the program of SARA issue and attacking the rival personality. It is the proof of how cheap is Anies program and also the proof for his incompetency'.

26. AHY bilang jangan salah pilih Gubernur nyeselnya 5tahun. Gue mau kasih tau gue udah ketipu sama bapaknya selama 10 tahun (PP-15).

'AHY warned us to not choose the wrong one. I just want you to know that i regret to choose your swindler father for 10 years'.

27. Aksi bela Ahok hanya 500 orang, bikin ulah bahkan anarkis. Aksi bela islam jutaan orang, damai, rapi dan tak ada yang tersakiti. BEDA KUALITAS! (WI-6).

'Action for Ahok just got 500 participants; however, it was chaos and anarchist. Action for Islam have a million but peaceful, well-organized and safe. QUALITY!'

28. "Kalau terima langsung massa aksi 313, Presiden nggak bisa kerja". Kenapa kalo ngurus Kambing ada waktu ya?Pak, sebenarnya bapak kerja untuk kambing, apa buat rakyat sih? (WI-29)

'If president accept the 313 action mass, the taks is undone. However, the president have a time for the goat. Sir, Are you a president of people of the goat?'.

Clear violation of tact principle happens in the data (22) through maximalization of social and psychological harm to the other supporting community as the addressee because the utterance is forceful and reproachful. Violations of sympathy principle appear in the data (23). In this utterance, there is the maximization of the antipathy towards the addressee with through blatant condemnation. In the data (24), the speaker violates agreement principle through an exaggerated view by $\mathrm{him} /$ herself. Those violations generally are caused by one-sided claim which is not yet clear.

Furthermore, violation of consideration principle also occurs in data (25). There is maximization of the dislike towards the addressee through disparagement without 
considering some points. The violation of generosity principle on data (26) is due to maximizing social loss without considering the slightest goodness of the other candidates as the face of the addressee. The violation of the modesty principle in the data (27) is caused by the sarcasm which is too sharp and direct, thus maximizing the disrespect for the addressee. In the data (28), the violation toward approbation principle is done by comparing human being with animal. This act is exacerbated by obvious expression of hate toward the head of a state.

\section{DISCUSSION}

Based on the analysis of data on four elements of politeness as the object of study in this research, there are three main discussion as follows. Firstly, the supporting community tends to choose expressive speech act (46 data), figure of speech type sarcasm (43 data), bald on-record strategy (59 data), as well as total violations towards the politeness principle (100 data). Furthermore, $62 \%$ of total data are on 'Face Threatening Acts' (FTA) with a 'high' level according to parameters proposed by Brown and Levinson (1987) in the form of criticism, humiliation, accusation, indictment, castigation, etc. The divisive statement, racism, blasphemous language, harassment, and false identification towards other candidate as the representation of addressee obviously threaten the 'negative face' of the recipient, so it finally drags the level of politeness, which is in the classification of 'impolite.' Likewise, the 'indirectness scale' proposed by Blum-Kulka (1985) clearly proves that "The more direct an expression is conveyed, so it is the less polite". This classification is marked with 'red' color in Table 1, indicating that the speech used is 'dangerous'.

Secondly, the next combinations that are quite dominant are commisive speech act (43 data), figure of speech type cynicism (35 data), and negative politeness strategy (31 data) which posits the type of speech in a 'quite high' position of vulnerability based on the parameters proposed by Brown and Levinson (1987). Matters relating to command, threat, warning, challenge, hatred, anger, etc. clearly prove to threaten the 'negative face' so the politeness classification is 'less polite'. This classification is marked with 'yellow' color in Table 1, indicating that the speech used is 'somewhat dangerous'

Thirdly, the less dominant combinations are directive speech act (13 data), figure of speech type irony, alusio, and paradox (24 data), and positive politeness and vague strategy (12 data). So, around $12 \%$ from total utterance is in 'not high enough' category. In accordance with the parameters of Brown and Levinson (1987), if the speech is delivered in the form of directives, warnings, challenges, appeals, then that speech is less likely to threaten the 'face' of the addressee; consequently the politeness is in the classification of 'quite polite'. The above phenomena is in line with the parameter of Grice (in Pranowo, 2009) "to choose an utterance that does not underestimate the status of recipient..." and indirectness scale of Blum-Kulka (1985) "the more indirect a statement, the more polite that utterance". This classification is marked with 'green' color in Table 1, indicating that the speech used is 'less dangerous'.

However, in general reality, the supporting community of governor candidates do not choose these conventional ways. Both group tend to choose a vulgar, slightly brutal, and disapproval way of speaking which have highpotential to threaten the face and to create an 'impolite' utterance.

The result of the research, in fact is still relevant to the research conducted by Rahyono et al. (2005); that is, the main characteristic of information delivery in the New Order Post media, was "straight forward news followed by a hyperbolic and abusive language, such as censure, complaints, anger, ridicule, and humiliation." Even though the research has long been conducted; however, the fact still occurred on Jakarta election discourse, either in the mass media or in the social media.

\section{Conclusion}

Based on previous analysis and discussion, the portrait of politeness in the language by the supporting community in the discourse of Jakarta election can be classified into three categories, namely 'impolite' (62\%), 'less polite' $(36 \%)$, and 'slightly polite' (12\%). Based on the percentage figures that appear, the level of politeness in the language of the supporting community in the discourse of Jakarta election in general is 'impolite'.

This fact then indicates that politeness as a system of interpersonal relationships is designed to facilitate interaction by minimizing the potential for conflict and confrontation (Lakoff, 1975), and politeness as a property agreed by speakers and addressee not to transcend their rights in speaking (Frasser, 1980), and politeness as an effort to create mutual trust and minimization of the occurence of disrespectful statement (Leech, 1993) are not used and are not adhered to by the supporting communities in this case.

Thus, the opinion of Yaolong (2008) about politeness as a complex phenomenon and always changing due to the dynamic interaction between language, culture, and social values is an inevitable fact that also appears in the context of Jakarta election.

However, the fact cannot be tolerated due to being very disturbing of the people's lives. How many social relationships are damaged as well as how many cultural values are marginalized by the language? It is therefore a chaotic language expression which is full of blasphemy, hatred, and verbal abuse during Jakarta election must be returned to its main function as an effective and polite communication tool so as to reflect civilized society culture, appreciate differences, and uphold unity. 


\section{REFERENCES}

Agustina SR (2017). Verbal violence during Jakarta Election: Revealing politeness level in political-discourse society in Proceedings of National Seminar on Language and Indonesian Literature in the Grip of Multicultural Society. Padang: Universitas Negeri Padang, pp. 130-139.

Blum-Kulka S (1985). Indirectness and politennes in requests: Same or diffirent, at the International Pragmatics Conference, Viareggio, Italy.

Brown P, Levinson SC (1987). Politeness of some universals in language usage. Cambridge University Press.

Chaer A, Leoni A (2010). Sociolinguistics; an introduction. Jakarta: Rieneka Cipta

Endraswara S (2011). Literature research methodology: epistemology, model, theory, and applications: Yogyakarta: CAPS

Frasser B (1980). Conversational Mitigation. J. Pragmat. 4:341-350.

Gunarwan A (1994). Pragmatics: bird's eye view, in Dardjowidjojo (Editor). Accompanying true colleagues: for Mr. Ton. Jakarta: Universitas Katolik Atmajaya.

Keraf G (2007). Diction and language style: Composition. Jakarta: PT Gramedia Pustaka Utama.

Leech G (1993). Principle of pragmatic. London: Longman (terjemahan MDD Oka), Jakarta: Universitas Indonesia.

Levinson SC (1983). Pragmatic. Cambridge: University Press.

Moleong LJ (2010). Qualitative research methods: Revised. Bandung: Remaja Rosdakarya.
Pranowo (2009). Speaking politely. Yogyakarta: Pustaka Pelajar.

Rahardi RK (2000). Imperative politeness of the Indonesian language Yogyakarta: Duta Wacana.

Rahyono RX et al. (2005). The wisdom of language: a Pragmatic Study on the profile of the post-new order era mass media language. Jurnal Makara, Sosial, Humaniora, 9(2):46-56.

Searle JR (1975). Indirect speech act, in Cole, P \& Morgan, J.L. (ed.) Syntax and semantic Vol. 3: Speech acts. New York: Academic Press.

Semi MA (1993). Method literature reseach. Bandung: Angkasa.

Sherry HQ, Agustina SR, Juita N (2012). Speech acts of ilocution in humor book dismantle the story of Cikeas by the work of Jaim Wong Gendeng and its implications in Indonesian Language Learning. Jurnal Pendidikan Bahasa dan Sastra Indonesia 1(1):62-70.

Syahrul R (2008). Pragmatics of language politeness revealing phenomenon of Indonesian language teachers and students. Padang: UNP Press.

Wijana IDP (1996). Pragmatic basics. Yogyakarta:ANDI.

Yaolong $S$ (2008). A Pragmatics study of politeness maxims in contemporary Chinese. Int. Forum Teach. Stud. 4(2):27-59.

Yule G (2006). Pragmatics (Translation by Wahyuni, IP) Yogyakarta: Pustaka Pelajar. 